\title{
Diacronie
}

Studi di Storia Contemporanea

$N^{\circ} 31,3 \mid 2017$

"Le armi della politica, la politica delle armi"

\section{Italian Military Occupation in Europe: the Historiographical Developments}

An Introduction

Niall MacGalloway

\section{(2) OpenEdition}

\section{Journals}

\section{Electronic version}

URL: http://journals.openedition.org/diacronie/6158

DOI: 10.4000/diacronie.6158

ISSN: 2038-0925

\section{Publisher}

Association culturelle Diacronie

\section{Electronic reference}

Niall MacGalloway, « Italian Military Occupation in Europe: the Historiographical Developments », Diacronie [Online], N ${ }^{\circ} 31,3$ | 2017, Online since 29 October 2017, connection on 24 September 2020. URL : http://journals.openedition.org/diacronie/6158; DOI : https://doi.org/10.4000/diacronie.6158

This text was automatically generated on 24 September 2020.

Creative Commons License 


\title{
Italian Military Occupation in Europe: the Historiographical Developments
}

\author{
An Introduction
}

Niall MacGalloway

1 Between 1940 and 1943, Fascist Italy invaded and occupied portions of France, Greece, and the dismembered Yugoslav territories. The occupation of these areas augmented those already occupied or incorporated into the Italian Empire in Albania and in North and East Africa. Although Stephen Azzi is arguably correct in his assertion that «no aspect of

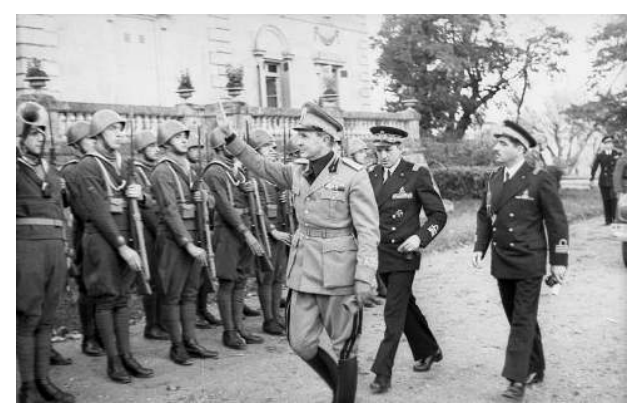
interwar Italian history has received more attention than fascist foreign policy», the study of Fascism's military occupations, particularly in Europe, has been more peripheral until relatively recently ${ }^{1}$. Fascist Italy's occupations in Europe have been consistently overshadowed by the far larger swathes of territory occupied by Germany. Nonetheless, a growing body of work has begun to emerge addressing this imbalance. Indeed, Davide Rodogno's claim that the failure of Fascist Italy's zones of occupation do not make them any less deserving of historical investigation represents the driving force behind much of the existing further work into these projects ${ }^{2}$.

2 Few areas of historiography, with the exceptions perhaps of the Spanish Civil War and the rise of Nazism in Germany, have received such rich historiographic treatment and debate than the Second World War. Much of this historiography has undoubtedly focused, however, on the German war effort, and the Allied conflict with Germany. Amongst American historians, deviation from this trend has been in the direction of examination of the Japanese war in the Pacific, despite the large Italian American 
population in the United States. Panoramic histories of the Second World War, particularly Churchill's own six-volume study and Basil Liddell Hart's history of the conflict, frequently reduced the role of Italy to merely the opponents faced by the Allies in North Africa ${ }^{3}$. Although comprehensive studies portrayed the Italians as relatively uninfluential actors in the Second World War, a far smaller selection of monographs did examine Italy's actions in the conflict. Many, however, failed to engage with Italian military occupations. Perhaps the most prominent in English, Denis Mack Smith's Mussolini's Roman Empire, focuses on the drive for foreign conquest, and gives no real insight into the governance of those territories occupied by Italy ${ }^{4}$.

During the early decades following the end of the war, work on Italy during the Second World War largely appeared in the form of biographies of Mussolini. Although Fascist Italy and the Second World War were crucial backdrops to these biographies, very few provided any insight into Italy's actions within her occupied territories. Mack Smith's analysis of Mussolini's foreign policy was largely governed by the idea that Mussolini was more concerned with headline-grabbing acts of propaganda, rather than any coherent policy ${ }^{5}$. Richard Bosworth's biography, whilst a more balanced account of Mussolini, does not provide any real insight to the occupied territories, instead keeping to its subject matter ${ }^{6}$. Indeed, even Renzo De Felice's monumental biography of Mussolini, a biography which has often been utilised by historians as a history of the regime itself, says curiously little about the war, almost completely ignoring the fact that Fascist Italy occupied European territories 7 . Biographies of Mussolini, therefore, and many of the regimes leading figures have been of limited use to those wishing to understand how Fascist Italy governed her zones of occupation. Even those focused on the Italian Minister for Foreign Affairs, Galeazzo Ciano, have offered little on the occupations themselves, whilst Ciano's diary has offered similarly little ${ }^{8}$.

4 The evolution of historical study into Fascist Italy's zones of occupation has undoubtedly benefited from the increasing nuances of study into Italian foreign policy, both in the lead up to and during the Second World War. Revisionist historians, including MacGregor Knox, Esmonde Robertson and De Felice, began to argue from the 1960s onwards that Fascist foreign policy, if not based upon a specific programme, existed out with the traditional image of Mussolini as nothing more than a buffoon. Although these historians debated the extent to which Fascist foreign policy was rooted in both imperialism and traditional Italian foreign policy goals, and how far Mussolini utilised foreign policy merely as a tool to improve his domestic standing, the combined efforts of revisionist historians meant that Fascist foreign policy became a subject in its own right ${ }^{9}$.

Official studies published by Italian government in the 1970s and 1980s opened new avenues of study on the manner in which the Italian armed forces had governed their zones of occupation. The extension of the Documenti Diplomatici Italiani into the war years brought some of the most important diplomatic documents from the Archivio Storico del Ministero degli Affari Esteri (ASMAE) into print for the first time. Although self-evidently an examination of Italian actions at the highest diplomatic level, the documents demonstrated the scale of Italian diplomatic activity in Europe and helped demonstrate a distinction between Italian and German actions during the conflict. These documents were augmented by a steady stream of official studies each of which took as their focus a particular geographic region. The Stato Maggiore dell'Esercito published a series of geographically specific monographs, yet even the more recent of 
these, for example that published by Domenico Schipsi on the Italian occupation of France, are almost entirely reliant upon military $\operatorname{archives}^{10}$.

6 From the 1990s onwards, an increasing number of monographs and articles began to examine the manner in which Italy's zones of occupation were governed, both on a national and microcosmic scale. Romain Rainero's Mussolini e Pétain, coupled with important monographs by Massimo Borgogni and Enrica Costa Bona laid foundations for Italian relations with France, albeit almost exclusively at a diplomatic level ${ }^{11}$. Although diplomatic relations between Italy and what remained of Yugoslavia and between Italy and Greece were less formal than between Italy and France, early monographs on these fronts largely examined Italian policy at a high level, or from a military point of view. Marco Cuzzi's L'occupazione italiana della Slovenia utilisation of military archives resulted in a monograph which, whilst thorough, focused on the military aspects of the occupation ${ }^{12}$.

7 The continued publication of specialist monographs has ensured that the historiography surrounding the Italian zones of occupation has enriched and built upon official publications and examinations of Italian inter-war diplomacy to the point where historians can make the claim that the field forms an integral part of Fascist foreign policy. Perhaps the most important single monograph on the Italian zones of occupation is that of Davide Rodogno. Rodogno's examination of how Fascist theorists and politicians conceived of Italy's place in a post-war Europe and important thematic study into Italian zones of occupation across Greece, Yugoslavia, France, and Albania have formed a cornerstone for many of the more specialist monographs which followed $^{13}$. Marco Clementi and Sheila Lecoeur's examinations of Italian governance in Greece have helped shed light upon the important role played by Italy in wartime Greece, augmenting the work of Mark Mazower which has hitherto focused more closely on the German occupation ${ }^{14}$. Steven Pavlowitch and Eric Gobetti have written important studies of the Italian occupation of Yugoslavia, the latter strongly rebutting the notion that the Italian occupation was a comparatively gentle experience ${ }^{15}$. Debates over the severity of the Italian zones of occupation have coloured many emerging monographs. The concept of the bravo italiano has been thoroughly explored by Filippo Focardi, and the influence of the question has been reflected in new monographs. Amedeo Osti Guerazzi has explored the severity of punitive actions carried out by the Italian army in Slovenia, whilst examinations of the Italian zone of occupation in France by Jean-Louis Panicacci and Emanuele Sica have come to differing conclusions as to how occupier and occupied interacted ${ }^{16}$.

It is hoped that the contributions in this issue build upon the historiography and go beyond merely "filling the gaps". Redi Halimi's historiographic overview of the Italian occupation of Albania not only provides a solid introduction to the existing literature, but also points to future lines of study thanks to increasing accessibility in both Italian and Albanian archives. It helps tie together the idea argued by, amongst others, Davide Rodogno that any examination of the spazio vitale must include Albania as many ideas and concepts were trialled there. Francesco Mantovani help paint microcosmic pictures of the Italian occupation of Yugoslavia, which allow us to focus the lens more closely of the region. Yet these studies, whilst more specific than the monographs of $\mathrm{H}$. James Burgwyn and Eric Gobetti, extend beyond pointillism and help us to raise questions surrounding ideology, relations between the armed forces and the civilian population, and to understand the activities of the Italian occupation beyond merely controlling 
armed resistance ${ }^{17}$. Sanela Schmid's article examines food supply in Italian-occupied Croatia, and gives insight into Italo-German alliance and the rivalry within it. It makes an important contribution to not only this field, but to readers interested the social dimensions of the Italian occupation of Croatia.

It is hoped, therefore, that this volume shall bring interesting and exciting new contributions on the Italian zones of occupation and the spazio vitale to the forefront. It has aimed to bring together young scholars working in new and underutilised archives and examining sources from fresh perspectives in order to re-dress the balance between historiography focusing on the Italian military occupations in Europe and those carried out by Germany. These articles help to demonstrate the scale of activities carried out by Italy in these zones of occupation, and as such are fascinating reading to all of those who carry out study in this area.

\section{NOTES}

1. AZZI, Stephen Corrado, «The Historiography of Fascist Foreign Policy», in The Historical Journal, 36, 1/1993, pp. 187-203, p. 187.

2. RODOGNO, Davide, «Le nouvel ordre fasciste en Méditerranée, 1940-1943: presupposes, idéologiques, visions et velléités», in Revue d'histoire moderne et contemporaine, 55, 3/2008, pp. 138-156, pp. 138-139; RODOGNO, Davide, Fascism's European Empire. Italian Occupation during the Second World War, Cambridge, Cambridge University Press, 2006.

3. CHURCHILL, Winston, The Second World War, 6 voll., London, Houghton, 1948-1953; LIDDELL HART, Basil, The History of the Second World War, London, Pan, 1970.

4. MACK SMITH, Denis, Mussolini's Roman Empire, London-New York, Longman, 1976.

5. MACK SMITH, Denis, Mussolini, London, Weidenfeld and Nicolson Ltd, 1981.

6. BOSWORTH, Richard, Mussolini, London, Bloomsbury, 2002. Bosworth's biography focuses on Mussolini as an individual and his place in the regime, for an analysis of the regime see: BOSWORTH, Richard, Mussolini's Italy, Life under the Dictatorship,1919-1945, London, Penguin, 2005.

7. Mack Smith makes the accusation that De Felice's study reveals too little about the Second World War, MACK SMITH, Denis, Le guerre di Mussolini: riserve sulla biografia di De Felice, in CHESSA, Pasquale, VILLARI, Francesco (a cura di), Interpretazioni su De Felice, Milano, Baldini \& Castoldi, 2002, pp. 29-66.

8. GUERRI, Giordano Bruno, Ciano, Milano, Bompiani, 2011; CIANO, Galeazzo, Diario, Milano, BUR, 1990.

9. ROBERTSON, Esmonde M., Mussolini as Empire Builder, Europe and Africa, 1932-36, London, Macmillan, 1977; DE FELICE, Renzo, Mussolini, 4 voll., Torino, Einaudi, 1965-1997; DE FELICE, Renzo, Le interpretazioni del fascismo, Bari, Laterza, 1969.

10. SCHIPSI, Domenico, L'occupazione italiana dei territori metropolitani francesi, 1940-1943, Roma , Ufficio Storico del Stato Maggiore dell'Esercito, 2007.

11. RAINERO, Romain, Mussolini e Pétain. Storia dei rapporti tra l'Italia e la Francia di Vichy (10 giugno 1940 - 8 settembre 1943), Roma, Stato Maggiore dell'Esercito, 1990; BORGOGNI, Massimo, Mussolini e la Francia di Vichy, Dalla dichiarazione di guerra al fallimento del riavvicinamento italo-francese (giugno 
1940 - aprile 1942), Siena, Nuova Immagine Editrice, 1991; BORGOGNI, Massimo, Italia e Francia, Durante la crisi militare dell'Asse (1942-1943), Siena, Nuova Immagine Editrice, 1994; COSTA BONA, Enrica, Dalla guerra alla pace: Italia-Francia, 1940-1947, Milano, Franco Angeli, 1995.

12. CUZZI, Marco, L'occupazione italiana della Slovenia (1941-1943), Roma, Edizione Ufficio Storico Maggiore dell'Esercito, 1998.

13. RODOGNO, Davide, Fascism's Europe Empire, cit.

14. CLEMENTI, Marco, Camicie nere sull'Acropoli. L'occupazione italiana in Grecia (1941-1943), Roma, DeriveApprodi, 2013; LECOEUR, Sheila, Mussolini's Greek Island. Fascism and the Italian Occupation of Syros in World War II, London, I.B. Tauris, 2009; MAZOWER, Mark, Inside Hitler's Greece, London, Yale University Press, 1993.

15. PAVLOWITCH, Steven, Hitler's New Disorder: the Second World War in Yugoslavia, London, Hurts, 2009; GOBETTI, Eric, Alleati del nemico. L'occupazione italiana in Jugoslavia (1941-1943), Roma-Bari, Laterza, 2013; GOBETTI, Eric, L'occupazione allegra. Gli italiani in Jugoslavia (1941-1943), Roma, Carocci, 2007.

16. FOCARDI, Filippo, Il cattivo tedesco e il bravo italiano. La rimozione delle colpe della seconda guerra mondiale, Roma-Bari, Laterza, 2013; OSTI GUERRAZZI, Amedeo, The Italian Army in Slovenia. Strategies of Antipartisan Repression, 1941-1943, Basingstoke-New York, Palgrave, 2013; PANICACCI, Jean-Louis, L'occupation italienne: Sud-Est de la France, juin 1940 - septembre 1943, Rennes, Presses Univeritaires de Rennes, 2010; PANICACCI, Jean-Louis, En territoire occupé. Italiens et allemands à Nice, 1942-1944, Paris, Éditions Vendémiaire, 2012; SICA, Emanuele, Mussolini's Army in the French Riviera. Italy's Occupation of France, Urbana, University of Illinois Press, 2015.

17. BURGWYN, H. James, Empire on the Adriatic, Mussolini's Conquest of Yugoslavia, 1941-1943, New York, Enigma Books, 2005.

\section{AUTHOR}

\section{NIALL MACGALLOWAY}

Niall MacGalloway is PhD student at the University of St Andrews in Scotland. His thesis is entitled The Italian Occupation of South-Eastern France, 1940-43, and his interests focus on the Second World War, Italo-French relations, and inter-war Italy and France.

URL: < http://www.studistorici.com/progett/autori/\#MacGalloway > 